\title{
Opening up the Turkish E conomy in the Context of the Customs Union with EU
}

\author{
Sübidey Togan \\ Bilkent University, Ankara
}

\begin{abstract}
The paper consider the Turkey-EU customs union (CU). After reviewing bri efly the developments in Turkey-EU relations the paper studies the structure of protection that prevailed prior to the formation of the $\mathrm{CU}$ as well as struc ture of protection that will prevail when all of the adjustments required by the CU will be completed. The resource allocation effects of the CU are studied using nominal and effective protection rates. Besides the liberalization of trade the $\mathrm{CU}$ introduces new rules and disciplines that will effect the functioning of markets in Turkey. With the formation of CU Turkey is confronted with reduc tions in annual tax revenue. The paper studies the possible effects of tax rev enue losses as well as the effects of the CU on FDI in-flows.
\end{abstract}

\section{Introduction}

After pursuing inward oriented development strategies for fifty years Turkey switched over to outward oriented policies in 1980. The policy of fur- 
customs union (CU) starting January 1, 1996. The purpose of this paper is to analyze what forming the $\mathrm{CU}$ with the EU entails for Turkey and also to study the effects of the CU. Section II considers the developments in Turkey-EU relations. Section III concentrates on the study of the structure of protection in Turkey and the effects of tariff changes. Section IV analyzes the effects of new rules and disciplines introduced through the Customs Union Decision (CUD). Section $V$ discusses the issues related with trade in agricultural products. M acroeconomic effects are studied in section VI. The paper concludes with a short assessment of the CUD.

\section{Turkey and the European Union}

Turkey's application for association with the European Economic Community (EEC) was made in 1959. The application ultimately resulted in the signing of the Association Agreement in 1963. According to the Agreement, the association was to be implemented in three stages: a preparatory stage, a transitional stage and a final stage. During the preparatory stage, the EEC granted unilateral concessions to Turkey in the form of agricultural tariff quotas and secured financial assistance. In the meantime, Turkey did not have to change its trade regime. In 1967 Turkey lodged its application for negotiations on entering the transitional stage. The Additional Protocol to the Ankara Agreement was signed in 1970, and became effective in 1973. The basic aim of the Additional Protocol is the establishment of a CU. In 1995 it was agreed at the Association Council meeting that Turkey would create a CU between Turkey and the EU starting on January 1, 1996. The CUD requires that Turkey

- eliminates all customs duties, quantitative restrictions, all charges having

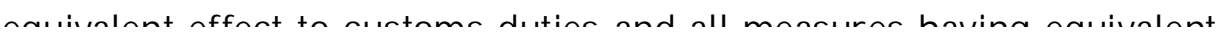


instruments relating to the removal of technical barriers to trade. The list of these instruments is to be laid down within a period of one year. Effective co-operation is to be achieved in the fields of standardization, quality and certification.

- approximates and implements EU's commercial policy regulations including procedures for administering quantitative quotas, anti-dumping rules and procedures for officially supported export credits. In addition Turkey adopts EU's textile and garments agreement with third countries.

- adjusts its policy in such a way as to adopt the common agricultural policy (CAP) measures required to establish freedom of movement of agricultural products.

- adopts EU's customs provisions in the fields of (i) origin of goods, (ii) customs declarations, (iii) release for free circulation, (iv) customs debt and (v) right of appeal.

- insures adequate and effective protection and enforcement of intellectual, industrial and commercial property rights. Turkey will implement the Trade Related Aspects of Intellectual Property Rights (TRIPS) Agreement by 1999 .

- adopts the EU competition rules, including measures regarding public aid within two years. But aid given for structural adjustment purposes will be considered compatible with the functioning of $\mathrm{CU}$ for another five years. Turkey shall ensure that its legislation in the field of competition rules is made comparable with that of the Community, and is applied effectively.

The CUD is silent on four issues: (i) supply of services, (ii) establishments, (iii) movement of capital, and (iv) movement of labor.

Consideration of Turkey-EU trade data reveals that in 1995 Turkish 
Table 1

B asic Data on the Turkish Foreign Trade During 1995

Table 1a: Foreign Trade and its Territorial Composition

\begin{tabular}{|l|c|c|c|c|}
\hline & $\begin{array}{c}\text { Exports } \\
\text { (M illion \$) }\end{array}$ & $\begin{array}{c}\text { Export } \\
\text { Share }\end{array}$ & $\begin{array}{c}\text { Imports } \\
\text { (M illion \$) }\end{array}$ & $\begin{array}{c}\text { Import } \\
\text { Share }\end{array}$ \\
\hline EU-15 & 11,078 & 51.20 & 16,861 & 47.22 \\
Germany & 5,036 & 23.28 & 5,548 & 15.54 \\
Italy & 1,457 & 6.73 & 3,193 & 8.94 \\
UK & 1,136 & 5.25 & 1,830 & 5.12 \\
France & 1,033 & 4.77 & 1,996 & 5.59 \\
NAFTA & 1,618 & 7.48 & 4,102 & 11.49 \\
Former Soviet Union & 2,104 & 9.72 & 3,362 & 9.42 \\
\hline Total & 21,636 & 100 & 35,708 & 100 \\
\hline
\end{tabular}

\section{Table 1b: Commodity Composition of Exports and Imports of Turkey in Its Trade with EU}

\begin{tabular}{|l|l|l|c|c|}
\hline \multicolumn{2}{|c|}{ SITC } & \multicolumn{1}{|c|}{ Commodity } & Exports & Imports \\
\hline 1 & $0-08+41+42$ & Food & 14.60 & 3.87 \\
2 & 1 & Beverages and Tobacco & 1.21 & 0.52 \\
3 & $08+22+43$ & Other Food Items & 0.13 & 0.16 \\
4 & $2-22-27-28$ & Agricultural Raw M aterials & 1.95 & 2.85 \\
5 & $27+28$ & Crude Fertilizers and M etallic Ferrous Ore & 2.33 & 3.62 \\
6 & 3 & Energy & 1.40 & 0.89 \\
7 & $67+68$ & Iron and Steel and Non-Ferrous M etals & 4.16 & 5.71 \\
8 & $65+84$ & Textiles and Clothing & 48.27 & 4.80 \\
9 & $61+83+85$ & Hides and Leather & 0.49 & 1.08 \\
10 & $63+82$ & Wood M anufactures and Furniture & 0.70 & 0.63 \\
\hline
\end{tabular}


share of $48.27 \%$ food with a share of $14.6 \%$ and machinery and transport equipment with a share of $13.79 \%$ On the other hand the three commodities with the highest shares in Turkish imports from the EU are machinery and transport equipment with a share $42.53 \%$ chemicals and rubber products with a share of $15.66 \%$ and miscellaneous manufactured articles with a share of $12.16 \%$

\section{Structure of Protection and Effects of Changes in Tariff Rates}

With the formation of the CU between Turkey and EU industrial goods will circulate freely between the parties, Turkey will implement the Community's CCT on goods from third parties and adopt by the year 2001 all of the preferential trade agreements the $\mathrm{EU}$ has concluded over time. To calculate the effect of these changes on the Turkish economy one has to obtain figures for nominal protection rates (NPR) for trade with EU and also with third countries for periods before and after the formation of the $\mathrm{CU}$. For the period before the formation of the CU we consider the year 1994 and for the period after the formation of the $\mathrm{CU}$ the year 2001 when Turkey is supposed to have adopted all of the preferential agreements of EU. The objective of this section is to determine the resource allocation effects of the CU.

Column 1 of Table 2 reports the NPR's in trade with EU during 1994. The Table reveals that the economy wide NPR during 1994 in trade with EU has amounted to $10.22 \%$ when weighted by the sectoral import values. Consideration of the frequency distribution of the sectoral NPR's reveals that among the 49 tradable goods industries considered, there were three industries in 1994 which had a NPR higher than 50\% in trade with EU, and that there were 33 industries which had a NPR less than 20\%in trade with EU. Examination of sectoral NPR's reveals that the highest Turkish NPRs in trade with 
industries which had a NPR less than $20 \%$ In the case of trade with third countries we note that during 1994 the highest NPRs were in the sectors "processed tobacco" (99.91\%), "alcoholic beverages" (94.28\% and "fruits and vegetables" ( $72.62 \%$.

According to the CUD all industrial goods except the "European Coal and Steel Community" (ECSC) products circulate freely between the parties. In the case of ECSC products Turkey has signed a "Free Trade Agreement" (FTA) with EU in July 1996 as a result of which ECSC products will receive duty free treatment between the parties in three years time. In order to establish freedom of movement of agricultural products, Turkey according to the CUD will have to adjust its policy in such a way as to adopt the Common Agricultural Policy (CAP). But because of problems involved in adopting the CAP, agricultural commodities remain as yet outside the scope of the CU. The CUD requires that Turkey implements the Community's CCT on imports of industrial goods from third countries as of J anuary 1, 1996 and adopts by the year 2001 all of the preferential trade agreements EU has concluded over time. Hence in the case of trade with third parties a distinction has to be introduced for trade with EFTA countries, the M editerranean countries, the Central and Eastern European countries (CEEC), developing countries having GSP treatment and the Lomé Convention countries. Since with each of these country groups the EU has concluded preferential trade agreements Turkey in four years will be faced with different sets of tariff rates for different groups of countries. In the case of EFTA countries, CEEC and Israel, which have FTA's with the EU, the nominal tariff rates that will be applied by Turkey in the year 2001 on imports from these countries will be identical to those applied on imports from the EU. Thus the NPR's given in column 2 of Table 2 will have to apply to about $53.77 \%$ of imports, which is the average share of Turkish imports from the EU, EFTA, CEEC and Israel 
Table 2

Nominal Protection Rates before and after the Customs Union with E U

\begin{tabular}{|c|c|c|c|c|c|c|}
\hline $\begin{array}{l}1.0 \\
\text { Code }\end{array}$ & Sector Name & $\begin{array}{c}\text { NPR with EU } \\
\text { in } 1994\end{array}$ & $\begin{array}{l}\text { NPR with EU } \\
\text { after Customs } \\
\text { Union }\end{array}$ & $\begin{array}{c}\text { NPR with Third } \\
\text { Countries in } \\
1994\end{array}$ & $\begin{array}{l}\text { Average M FN } \\
\text { Tariff Rates } \\
\text { after Customs } \\
\text { Union }\end{array}$ & $\begin{array}{c}\text { Average Tariff } \\
\text { Rates for GSP } \\
\text { Beneficiaries } \\
\text { after Customs } \\
\text { Union }\end{array}$ \\
\hline 1 & Agriculture & 41.27 & 41.26 & 41.65 & 41.26 & 41.26 \\
\hline 2 & Animal husbandry & 3.48 & 1.37 & 4.18 & 1.37 & 1.37 \\
\hline 3 & Forestry & 0.01 & 0.01 & 0.10 & 0.01 & 0.01 \\
\hline 4 & Fishery & 47.92 & 47.84 & 54.08 & 47.84 & 47.84 \\
\hline 5 & Coal mining & 3.33 & 0.00 & 3.33 & 4.00 & 0.00 \\
\hline 6 & Crude petroleum & 0.00 & 0.00 & 0.00 & 0.00 & 0.00 \\
\hline 7 & Iron ore mining & 0.00 & 0.00 & 2.22 & 0.00 & 0.00 \\
\hline 8 & Other metalic ore mining & 0.13 & 0.00 & 1.21 & 0.00 & 0.00 \\
\hline 9 & Non-metallic mining & 9.09 & 0.00 & 11.02 & 0.95 & 0.95 \\
\hline 10 & Stone quarying & 1.95 & 0.00 & 2.18 & 0.02 & 0.00 \\
\hline 11 & Slaughtering and meat & 10.21 & 10.21 & 10.21 & 10.21 & 10.21 \\
\hline 12 & Fruits and vegetables & 72.49 & 68.01 & 72.62 & 68.01 & 68.01 \\
\hline 13 & Vegetable and animal oil & 16.31 & 16.31 & 16.38 & 16.29 & 16.29 \\
\hline 14 & Grain mill products & 41.33 & 41.02 & 41.33 & 41.02 & 41.02 \\
\hline 15 & Sugar refining & 28.79 & 28.79 & 28.79 & 28.79 & 28.79 \\
\hline 16 & Other food processing & 26.47 & 18.31 & 28.99 & 18.31 & 18.31 \\
\hline 17 & Alcoholic beverages & 72.10 & 5.25 & 94.28 & 11.28 & 7.35 \\
\hline 18 & Non-alcholic beverages & 56.92 & 0.00 & 69.81 & 14.83 & 0.00 \\
\hline 19 & Processed tobacco & 44.40 & 0.00 & 99.91 & 9.40 & 0.00 \\
\hline 20 & Ginning & 0.00 & 0.00 & 2.22 & 0.72 & 0.72 \\
\hline 21 & Textiles & 21.19 & 0.00 & 27.10 & 17.30 & 7.60 \\
\hline 22 & Clothing & 14.75 & 0.00 & 20.65 & 19.90 & 9.30 \\
\hline 23 & Leather and fur production & 7.85 & 0.00 & 12.57 & 10.20 & 2.80 \\
\hline 24 & Footwear & 24.40 & 0.00 & 35.70 & 22.50 & 9.10 \\
\hline 25 & Wood products & 15.25 & 0.00 & 18.97 & 2.00 & 0.05 \\
\hline 26 & Wood furniture & 26.22 & 0.00 & 32.64 & 5.50 & 0.00 \\
\hline 27 & Paper and paper products & 13.59 & 0.00 & 17.58 & 2.70 & 0.00 \\
\hline 28 & Printing and publishing & 8.23 & 0.00 & 10.79 & 4.52 & 0.00 \\
\hline 29 & Fertilizers & 8.22 & 0.00 & 16.38 & 8.10 & 0.00 \\
\hline 30 & Pharmaceutical production & 3.33 & 0.00 & 8.99 & 5.30 & 0.00 \\
\hline 31 & Other chemical production & 10.79 & 0.00 & 17.62 & 8.71 & 0.04 \\
\hline 32 & Petroleum refining & 22.54 & 0.00 & 24.35 & 2.70 & 0.00 \\
\hline 33 & Petroleum and coal products & 5.62 & 0.00 & 7.52 & 2.15 & 0.00 \\
\hline 34 & Rubber products & 19.57 & 0.00 & 23.91 & 5.60 & 0.03 \\
\hline 35 & Plastic products & 24.61 & 0.00 & 31.68 & 9.90 & 0.00 \\
\hline 36 & Glass and glass production & 16.85 & 0.00 & 21.94 & 5.76 & 0.00 \\
\hline 37 & Cement & 30.45 & 0.00 & 32.88 & 3.14 & 0.00 \\
\hline 38 & Non-metallic mineral & 18.33 & 0.00 & 23.21 & 5.47 & 0.00 \\
\hline 39 & Iron and steel & 8.00 & 0.00 & 10.70 & 5.50 & 3.30 \\
\hline 40 & Non-ferrous metals & 4.52 & 0.00 & 8.43 & 3.20 & 0.50 \\
\hline 41 & Fabricated metal products & 18.36 & 0.00 & 25.29 & 6.00 & 0.11 \\
\hline 42 & Non-electrical machinery & 7.36 & 0.00 & 12.50 & 4.40 & 0.00 \\
\hline & & & & & & \\
\hline
\end{tabular}


agricultural commodities from the levels in 1994. Similarly column 5 of Table 2 shows under the same assumption the average tariff rates for GSP beneficiaries. Thus we assume that the tariff rates Turkey will apply by 2001 will be as shown in columns 2, 4 and 5 of Table 2 . Note that by the year 2001 the average NPR for the EU countries and for countries the EU has FTA's with will be $1.34 \%$ for countries like USA, Japan and Canada 6.92\%and for GSP beneficiaries 2.71 .

As NPR's change in the economy domestic prices will change leading to movements along the production possibility frontier. Among the sectors there will be winners and losers. B efore turning to determination of these sectors let us consider the basic characteristics of the Turkish economy during 1990, the year when the latest input-output table was constructed by State Institute of Statistics. The data are reported in Table 3. The table reveals that the five non-service sectors generating the highest sectoral gross outputs and value addeds are "agriculture", "animal husbandary", "textiles", "other chemical production" and "other food processing". In terms of employment generated the top five non-service sectors are "agriculture", "animal husbandary", "textiles", "clothing" and "iron and steel". Column 4 of the Table shows the import penetration rates. According to the figures the sectors "other transport equipment", "crude petroleum", "shipbuilding and repairing", "non-electrical machinery" and "non-ferrous metals" are the five sectors with highest import penetration rates. Finally column 5 of the Table reveals that the top five industries with highest shares of sectoral exports to sectoral gross output are "fruits and vegetables", "clothing", "non-metallic mining", "shipbuilding and repairing" and "textiles".

To study the sectors that will be positively or adversely affected by the formation of the $\mathrm{CU}$ we first determine following the approach of Togan [1994] the effective protection rates (EPR) for the years 1994 and 2001. Con- 
Table 3

Basic Data on the Turkish Economy during 1990

\begin{tabular}{|c|c|c|c|c|c|c|}
\hline $\begin{array}{r}1.0 \\
\text { Code }\end{array}$ & Sector Name & $\begin{array}{c}\text { Gross } \\
\text { Output } \\
\text { (Million TL) }\end{array}$ & $\begin{array}{c}\text { Value } \\
\text { Added } \\
\text { (Million TL) }\end{array}$ & $\begin{array}{l}\text { Employment } \\
\text { (Thousand) }\end{array}$ & $\begin{array}{c}\text { Import } \\
\text { Penetration } \\
\text { Rate } \\
1 \%\end{array}$ & $\begin{array}{c}\text { Share of } \\
\text { Exports in } \\
\text { Total Output } \\
(\%)\end{array}$ \\
\hline 1 & Agriculture & $63,243,861$ & $47,675,738$ & 6511.2 & 3.35 & 3.24 \\
\hline 2 & Animal husbandry & $27,196,651$ & $13,312,171$ & 2800.0 & 1.71 & 1.26 \\
\hline 3 & Forestry & $3,375,123$ & $2,812,457$ & 49.3 & 12.49 & 0.78 \\
\hline 4 & Fishery & $2,624,856$ & $2,027,855$ & 16.3 & 0.55 & 3.53 \\
\hline 5 & Coal mining & $2,883,848$ & $2,015,300$ & 146.3 & 22.65 & 0.04 \\
\hline 6 & Crude petroleum & $1,857,558$ & $1,382,263$ & 3.4 & 84.28 & 0.24 \\
\hline 7 & Iron ore mining & 180,821 & 99,998 & 13.6 & 51.40 & 0.00 \\
\hline 8 & Other metalic ore mining & 537,786 & 342,535 & 6.1 & 14.41 & 21.61 \\
\hline 9 & Non-metallic mining & 874,930 & 747,321 & 9.9 & 13.14 & 40.77 \\
\hline 10 & Stone quarying & $1,607,640$ & $1,231,397$ & 18.2 & 9.11 & 1.96 \\
\hline 11 & Slaughtering and meat & $3,342,910$ & 701,302 & 28.2 & 14.67 & 7.77 \\
\hline 12 & Fruits and vegetables & $2,212,924$ & 736,856 & 46.7 & 6.95 & 66.53 \\
\hline 13 & Vegetable and animal oil & $4,023,697$ & $1,110,840$ & 35.4 & 18.51 & 10.87 \\
\hline 14 & Grain mill products & $6,165,931$ & 893,643 & 55.9 & 3.41 & 2.69 \\
\hline 15 & Sugar refining & $3,714,776$ & 986,580 & 83.5 & 19.01 & 0.22 \\
\hline 16 & Other food processing & $18,155,869$ & $4,326,698$ & 101.5 & 4.67 & 12.21 \\
\hline 17 & Alcoholic beverages & 2,331,812 & $1,619,371$ & 19.4 & 6.60 & 13.50 \\
\hline 18 & Non-alcholic beverages & $1,306,421$ & 562,940 & 18.3 & 2.89 & 7.47 \\
\hline 19 & Processed tobacco & $5,470,319$ & $2,973,729$ & 87.2 & 26.08 & 2.08 \\
\hline 20 & Ginning & $2,765,953$ & 450,266 & 53.7 & 19.54 & 11.13 \\
\hline 21 & Textiles & $26,074,710$ & $9,030,472$ & 483.7 & 8.26 & 22.65 \\
\hline 22 & Clothing & $11,044,816$ & $3,369,447$ & 173.3 & 8.62 & 43.59 \\
\hline 23 & Leather and fur production & $2,455,214$ & 876,556 & 42.3 & 19.61 & 16.26 \\
\hline 24 & Footwear & $1,763,004$ & 473,951 & 16.7 & 3.77 & 4.92 \\
\hline 25 & Wood products & $8,312,943$ & $2,651,977$ & 37.1 & 1.95 & 0.79 \\
\hline 26 & Wood furniture & $2,503,098$ & 772,642 & 11.8 & 2.22 & 2.41 \\
\hline 27 & Paper and paper products & $5,016,022$ & $1,624,450$ & 58.5 & 17.26 & 2.40 \\
\hline 28 & Printing and publishing & $3,251,627$ & 903,706 & 37.0 & 4.00 & 1.50 \\
\hline 29 & Fertilizers & $2,021,832$ & 541,052 & 25.9 & 29.67 & 8.13 \\
\hline 30 & Pharmaceutical production & $3,864,315$ & $1,666,585$ & 33.8 & 19.50 & 4.28 \\
\hline 31 & Other chemical production & $12,856,352$ & $4,628,072$ & 99.5 & 43.27 & 9.82 \\
\hline 32 & Petroleum refining & $22,450,561$ & $4,071,602$ & 13.6 & 13.60 & 3.34 \\
\hline 33 & Petroleum and coal products & $2,261,375$ & 718,034 & 13.5 & 9.43 & 0.63 \\
\hline 34 & Rubber products & $4,977,881$ & $1,475,994$ & 35.1 & 11.39 & 3.17 \\
\hline 35 & Plastic products & 2,893,954 & 857,388 & 41.2 & 11.85 & 3.96 \\
\hline 36 & Glass and glass production & $2,409,006$ & $1,245,383$ & 41.0 & 11.03 & 17.02 \\
\hline 37 & Cement & $4,773,275$ & $2,370,828$ & 50.2 & 2.70 & 3.30 \\
\hline 38 & Non-metallic mineral & $3,873,708$ & $1,889,891$ & 110.1 & 13.86 & 5.33 \\
\hline 39 & Iron and steel & $16,521,869$ & $3,341,047$ & 169.1 & 26.09 & 16.62 \\
\hline 40 & Non-ferrous metals & $4,853,119$ & $1,553,450$ & 54.5 & 55.92 & 11.50 \\
\hline 41 & Fabricated metal products & $9,838,073$ & $3,282,182$ & 109.8 & 13.06 & 3.98 \\
\hline 42 & Non-electrical machinery & $7,671,726$ & $3,174,390$ & 114.5 & 59.40 & 5.34 \\
\hline$\Delta 2$ & & $202 \cap 482$ & 715730 & & $76 h$ & 116 \\
\hline
\end{tabular}


there will be three industries which will have a EPR higher than $50 \%$ There will be 4 industries which will have EPR less than $50 \%$ but larger than $10 \%$ In 28 industries EPR will be less than $10 \%$ but positive. There will be 13 industries which will have negative EPR between 0 and - 100\% and the number of sectors with EPR less than - $100 \%$ will amount to 1 . Furthermore note that the economy wide EPR will decline from $18.44 \%$ in 1994 to $1.12 \%$ in 2001.

To study the effects of the $\mathrm{CU}$ on sectoral value addeds we subtract from the value of EPR for the year 2001 the value of EPR for the year 1994. The results are reported in column 3 of Table 4 . The Table reveals that the formation of the $\mathrm{CU}$ will lead among others to an increase in value added of the sectors "grain mill products", "clothing", and "agriculture". Of these sectors "agriculture" and "clothing" are among the top employment generating sectors. The Table further indicates that the most sensitive ten sectors in the Turkish economy consists of the following sectors: processed tobacco, petroleum refining, non-alcoholic beverages, alcoholic beverages, wood furniture, footwear, plastic products, cement, motor vehicles and wood products. Of these sectors "motor vehicles", "processed tobacco" and "cement" are among the relatively high employment generating sectors. "M otor vehicles" and "processed tobacco" face relatively high values of import penetration rates. The shares of exports in total gross outputs are relatively low. When interpreting the results consideration should be given to the fact that EPR's have been calculated under the assumption that exchange rate does not change. But with the formation of the $\mathrm{CU}$ the real exchange rate will devalue. As a result some of the marginal sectors shown as losers in Table 4 under fixed exchange rates will turn into winners with the real devaluation of the currency.

Regarding access to Turkish market we note that as a result of the forma- 
Table 4

Effective Protection Rates before and After the Customs Union with $E U$ and the Effects of the Customs Union

\begin{tabular}{|c|c|c|c|c|}
\hline $\begin{array}{c}1-0 \\
\text { Code }\end{array}$ & Sector Name & $\begin{array}{l}\text { EPR } \\
1994\end{array}$ & $\begin{array}{l}\text { EPR } \\
2001\end{array}$ & $\begin{array}{l}\text { Effects of } \\
\text { the Customs } \\
\text { Union }\end{array}$ \\
\hline 1 & Agriculture & 44.41 & 45.60 & 1.19 \\
\hline 2 & Animal husbandry & -18.61 & -21.65 & -3.04 \\
\hline 3 & Forestry & -0.28 & -0.01 & 0.26 \\
\hline 4 & Fishery & 56.58 & 58.10 & 1.52 \\
\hline 5 & Coal mining & 1.81 & 0.71 & -1.10 \\
\hline 6 & Crude petroleum & -0.78 & -0.06 & 0.72 \\
\hline 7 & Iron ore mining & -2.74 & -0.21 & 2.53 \\
\hline 8 & Other metalic ore mining & -1.68 & -0.13 & 1.54 \\
\hline 9 & Non-metallic mining & 9.91 & 0.47 & -9.45 \\
\hline 10 & Stone quarying & 0.29 & -0.09 & -0.37 \\
\hline 11 & Slaughtering and meat & 16.82 & 21.36 & 4.55 \\
\hline 12 & Fruits and vegetables & 291.43 & 285.80 & -5.63 \\
\hline 13 & Vegetable and animal oil & 6.62 & 8.76 & 2.14 \\
\hline 14 & Grain mill products & 281.46 & 301.45 & 19.99 \\
\hline 15 & Sugar refining & -54.25 & -35.98 & 18.27 \\
\hline 16 & Other food processing & 29.37 & 5.33 & -24.04 \\
\hline 17 & Alcoholic beverages & 145.43 & -13.57 & -159.00 \\
\hline 18 & Non-alcholic beverages & 128.03 & -40.69 & -168.72 \\
\hline 19 & Processed tobacco & 159.71 & -84.25 & -243.96 \\
\hline 20 & Ginning & -138.12 & -139.98 & -1.86 \\
\hline 21 & Textiles & 28.79 & 2.68 & -26.11 \\
\hline 22 & Clothing & 7.44 & 17.35 & 9.91 \\
\hline 23 & Leather and fur production & 10.73 & 0.43 & -10.30 \\
\hline 24 & Footwear & 67.17 & 15.12 & -52.05 \\
\hline 25 & Wood products & 37.28 & 0.67 & -36.61 \\
\hline 26 & Wood furniture & 62.67 & 1.67 & -61.00 \\
\hline 27 & Paper and paper products & 19.20 & -0.04 & -19.24 \\
\hline 28 & Printing and publishing & 4.42 & 1.04 & -3.39 \\
\hline 29 & Fertilizers & 13.63 & 1.78 & -11.85 \\
\hline 30 & Pharmaceutical production & 4.52 & 0.50 & -4.02 \\
\hline 31 & Other chemical production & 12.61 & 1.45 & -11.16 \\
\hline 32 & Petroleum refining & 180.44 & 3.75 & -176.69 \\
\hline 33 & Petroleum and coal products & -6.14 & 0.08 & 6.23 \\
\hline 34 & Rubber products & 33.95 & 1.29 & -32.66 \\
\hline 35 & Plastic products & 48.45 & 2.22 & -46.24 \\
\hline 36 & Glass and glass production & 25.54 & 1.26 & -24.28 \\
\hline 37 & Cement & 46.02 & 0.65 & -45.37 \\
\hline 38 & Non-metallic mineral & 26.79 & 1.30 & -25.49 \\
\hline 39 & Iron and steel & 11.10 & 2.88 & -8.22 \\
\hline 40 & Non-ferrous metals & 6.11 & 0.85 & -5.27 \\
\hline 11 & E shrirstad matal nrodiurte & 25 an & $\cap$ Ga & -2571 \\
\hline
\end{tabular}


Turkey. On the other hand trade of products within the province of the ECSC have been protected by the Community through application of nontariff barriers and anti-dumping measures. With the formation of the $\mathrm{CU}$ the NPR's applied by EU on imports of all industrial goods from Turkey have been reduced to zero.

The above considerations reveal that the CUD offers rapid liberalization of trade. However, there are loopholes in the liberalization provided through countervailing duties, antidumping procedures and safeguard measures which are mentioned in Articles 36, 42, 61 of the CUD. Article 36 specifies that as long as a particular practice is incompatible with the competition rules of the CU as specified in Articles 30-32 of the CUD and "in the absence of such rules if such practice causes or threatens to cause serious prejudice to the interest of the other Party or material injury to its domestic industry" the Community or Turkey may take the appropriate measures. Article 42 allows anti-dumping actions as long as Turkey fails to implement effectively the competition rules of the $\mathrm{CU}$ and other relevant parts of the acquis communautaire. In those cases Article 47 of the Additional Protocol signed in 1970 between Turkey and EC will remain in force. According to this article the Council Association, if it finds dumping, shall address recommendations to the persons with whom such practices originate. The injury party may take suitable measures if (i) the Council has taken no decision within 3 months and (ii) the dumping practices continue. In the case of a need of an immediate action, the party may introduce an interim protection measure such as anti-dumping duties for a limited duration. But the Council may recommend for the abolition of these interim measures. Finally Article 61 is about safeguards, which states that safeguard measures specified in Article 60 of the Additional Protocol will remain valid. According to Article 60 the Community (Turkey) may take 
Switzerland have close ties with the EU through the "Agreement on the European Economic Area". The Europe Agreements (EA's) concluded between CEEC and EU and the Turkey-EU CUD will extend at the latest by the year 2002 the freedom for movement of industrial goods to CEEC and Turkey. According to the long run design of European integration decided in 1993 in Copenhagen all EFTA countries and all nations with EA's can join the EU eventually. Since then, all countries with EA's have submitted membership applications. At the Cannes M eeting of 1995 it was decided to conclude FTA's with the M editerranean countries with the exception of Libya. If all goes well Russia, Ukraine, Belarus and M oldova will conclude FTA's with EU during the first part of the next century and all of the other former USSR members separate "Agreements on Partnership and Cooperation"s with EU. Freedom of movement of industrial goods among these countries would be achieved if each of the countries would sign the FTA's not only with EU but also with each other. This objective has been achieved partially by the Central European FTA and by the Baltic FTA. Turkey has recently signed FTA's with Israel and Hungary and is expected to sign within two years FTA's with the Czech Republic, Lithuania, Poland, Romania and the Slovak Republic. Once the CEEC and M editer ranean countries together with Russia, Ukraine and Belarus will conclude among themselves FTA's the European free trade and investment opportunities will extend over a region from $M$ orocco to Siberia and from Finland to Turkey.

The above considerations reveal that Turkey by the beginning of next century will face increased competition as European free trade and investment opportunities extend over most of Europe and M editerranean. With the CU the NPR's in trade with EU will go down from 10.22\% in 1994 to $1.34 \%$ in 2001, in trade with countries EU has FTA's with from $22.14 \%$ to $1.34 \%$ in trade with GSP countries from $22.14 \%$ to $2.71 \%$ and the M FN tariff 


\section{Customs Union Rules and Disciplines}

Turkey, by signing the CUD, has agreed to fulfill major tasks. These tasks include harmonization of commercial legislation as regards competition policy, state aids, intellectual and industrial property rights, and adoption of new rules on customs classification, valuation, rules of origin, technical regulations, standards and government procurements. Since the new rules and regulations are expected to effect the functioning of markets this section will concentrate on determining what these rules and regulations entail for Turkey.

We first consider the case of competition policies. Turkey during the 1980s and 1990s has used intensively three different tools of industrial policy. These tools are the investment incentives, the export incentives and the policy regarding state owned enterprises. In each case the government tried to obtain a preferred allocation of resources through the use of subsidies. Consideration of the system of production incentives used in Turkey until recently reveals that the government in order to promote investment in activities and areas regarded as desirable, has granted a number of incentives since 1967. The incentives, regulated by laws and decrees, have been directed to reducing the cost of investment, reducing the need for external financing, and increasing profitability. On the export side the governments using various types of export incentives during the 1980's and 1990's have been able to increase the profitability in export activities. Togan [1994] shows that the average economy wide export subsidy rate has decreased from 32\%in 1983 to 13\%in 1990. Finally, regarding the policy on state owned enterprises in Turkey, we note that the Turkish public enterprise sector is very large. The state had, for a long time, monopolies on tobacco, war weapons, railways, air-transportation, air and sea-port administration, post 
from the government in the form of direct transfers, equity injections and debt consolidation. There are also barriers to exit in Turkey. The aim of investment incentive schemes was to encourage investment and not to increase competition in the country. The credit incentives, which were supposed to promote entry, have often turned into instruments that reinforced the position of large incumbents. The government with its large share of the banking system has directly controlled the allocation of credit, and credit from public banks has often been extended not on the basis of commercial but of political considerations. For a long time there was no specific competition legislation or competition policy enforced in Turkey. To promote competition within the country, the country during the 1980's has eliminated quantitative restrictions in foreign trade and decreased substantially the level of nominal and effective protection rates. But the reduction of nominal and effective protection rates was not sufficient to ensure proper functioning of the markets. Recognizing the need for competition policies Turkey adopted its own competition policy with the "Law on the Protection of Competition" during December 1994.

Regarding the export regime we note that Turkey has joined the GATT Subsidies Code in 1985, agreeing to eliminate export subsidies by 1989. Since Turkey is a member of the World Trade Organization it accepts the GATT 1994 Agreement on Subsidies and Countervailing M easures (SCM ) which prohibits the governments from granting subsidies contingent upon either export performance or the use of domestic products.

Recently Turkey has eliminated most of the investment and export incentives. Within this context, GATT legal subsidies such as research and development subsidies and subsidies to facilitate the adaptation of plants to new environmental regulations have been introduced in 1995. It is stressed, that in the future, export subsidies in Turkey will be restricted to subsidies pro- 
structural adjustment program since 1983 privatization could not gain momentum until very recently mainly because of the various legal difficulties encountered.

The CUD requires that all agreements between undertakings which restrict or distort the competition, any abuse by one or more undertakings of a dominant position and any public aids which distorts competition are incompatible with the functioning of the customs union. The parties agree to adjust the state monopolies of commercial character at the end of the second year following the entry into force of the CUD so that no discrimination regarding the conditions under which goods are produced and marketed exist between nationals of the $M$ ember States and of Turkey. Furthermore Turkey shall ensure at the end of first year that no measures taken for public enterprises and for enterprises which have been granted special or exclusive rights should disturb trade between the two parties. Turkey by applying the competition rules effectively in the future will remove the barriers to entry into and to exit from the industry. Finally Turkey recognizes that in order to comply with the rules of the CUD it will have to stop subsidizing the public enterprises at the prevailing rates, align its state aid policies to those of EU, and it will have to apply the same competition policies to all firms whether private or public. This adjustment will certainly be costly, but unless the system of state aid is aligned to those in EU and unless competition rules will be applied effectively to all private and public firms, EU could use commercial defense instruments (anti-dumping and countervailing duties) against Turkey. The CU rules on subsidies will certainly increase competition in Turkey. When faced with intensified competition, domestic industries, which may have reaped monopoly and oligopoly profits in a relatively protected domestic market, will be forced to behave competitively. The concentration ratios in Turkey which are relatively high are expected to 
mercial relations are governed by competition rules, depends on the evolution of the level of integration between States. This integration will be accelerated as long as markets are harmonized through stronger competition enforcement and the phasing out of antidumping measures. Thus the success depends on the effective implementation of competition policies by the governments in Turkey.

Besides competition policies the CUD has clauses on intellectual, industrial and commercial property rights. The CUD requires that Turkey by January 1, 1996 accede to Stockholm Act of the Paris Convention for the protection of industrial property, Patent Co-operation T reaty, Nice Convention concerning the international classification of goods and services for the purposes of the registration of marks, Paris Act of the Bern Convention for the protection of literary and artistic works, and Rome convention for the protection of performers, producers of phonograms and broadcasting organizations. In addition Turkey will adopt the $\mathrm{EU}$ domestic legislation in the industrial property area, copyright and neighboring rights area. Turkey will insure adequate and effective protection and enforcement of intellectual property rights and it will implement the Uruguay Round Decision on TRIPS by 1999 and will implement Part III of the TRIPS Agreement by J anuary 1, 1996. Furthermore Turkey will have to adopt by J anuary 1, 1998 legislation to secure the patentability of pharmaceutical products and processes. Regarding copyright the CUD requires that piracy such as counterfeiting or boot-legging be effectively banned and that the terms of protection in cases of translation should not be inferior to fifty years in those cases in which the term is calculated on the basis other than the life of the person. Turkey shall accede by 1999 to the Protocol of the M adrid Agreement concerning the international registration of marks, the Budapest Treaty on the international recognition of the deposit of micro-organisms for the purposes 
property rights is framed in terms of costs and benefits 〈H oekman [1995]〉. The costs include increase in payments for propriety knowledge, price increases associated with greater market power for knowledge producers, the costs of displacement of pirate activities, the costs of additional $R \& D$ and the costs associated with administrative and enforcement of intellectual property rights protection. Potential benefits include new inventions fostered by higher levels of $R \& D$, greater technology, increased foreign trade, increased foreign direct investment flows and hence increases in per capita income of the country. Within this context the main task facing Turkey and the CEEC is the transformation of their intellectual property rights regime into effective instruments for the promotion of innovation, and hence increases in income.

In the case of standards the parties of the CUD stress the importance of effective co-operation of standardization, testing and certification. Following the CUD EU will assess the conformity of Turkish industrial products with its own legal requirements. Turkey aims to reduce the differences in the fields of standardization and conformity assessments. The CUD does recognize the importance of public procurements but does not specify any specific arrangements. Article 26 of the CUD requires that Turkey adopts EU 's customs provisions in the fields of (i) origin of goods, (ii) customs value of goods, (iii) introduction of goods into the territory of the customs union, (iv) customs declaration, (v) release for free circulation, (vi) movement of goods, (vii) customs debt and (viii) right of appeal. Furthermore for the effective functioning of the customs union the customs system in Turkey has to be modernized. A new draft customs law has been prepared replacing the customs law. The new draft customs law aims for speedy customs release, simplified procedures and full automation of customs procedures. Recently the customs administration has been going through extensive 


\section{Implications of the Agreement for Agricultural Products}

In Turkey agriculture has economy wide importance. During 1994-95 it accounted for about $14.5 \%$ of GDP and $46 \%$ of total employment in the economy. These shares have been falling over time. Value added per agricultural worker in Turkish agriculture amounts to only $21 \%$ of the value added per non-agricultural worker in Turkish non-agricultural sector. Furthermore a large fraction of Turkish population still lives in rural areas and the highest fertility rates in Turkey are found in rural areas, with out-migration from these areas also tending to be high. Although migration abroad has slowed down, internal migration towards urban areas continues at a fast pace. Turkey aims to ensure adequate levels of nutrition and food supplies at reasonable prices to consumers, raise production levels and yields while reducing the vulnerability of production to adverse weather conditions, increase farm incomes, improve their stability and develop rural areas. In pursuit of these objectives the government has implemented a set of measures based essentially on the support of producer prices, complemented by trade related measures, the subsidization of farm inputs, and transfers related to investments in infrastructural projects.

According to Articles 22-25 of the CUD Turkey in order to establish the freedom of movement of agricultural products will have to adjust its agricultural policy in such a way as to adopt the CAP measures. But is this possible? What does the adoption of CAP measures mean for Turkey. Turkey at current domestic prices is a net exporter of some and net importer of some other farm products. But those domestic prices when converted at equilibrium exchange rates will generally be below the EU domestic prices. Should Turkey be given tariff free access to $\mathrm{EU}$ agricultural markets at existing EU prices then supply could be expected to increase in Turkey. The output of 
annually. Unfortunately there are no similar studies for the Turkish case. It could be argued that Turkey could in principle support the agricultural sector by establishing a fund similar to the European Agricultural Guidance and Guaranty Fund (FEOGA) and that the amount of support would be similar in magnitude to that of CEEC. But who would provide the necessary funds in the Turkish case? Since Turkey cannot devote an amount similar to the figures given above from its own resources for the support of Turkish agricultural sector and since EU would be unwilling to bear the cost, the idea of establishing a fund similar to FEOGA in Turkey has to be abandoned. As a result it seems that freedom of movement of agricultural products between Turkey and EU cannot be achieved in the near future. We expect Turkey to keep the NPR's on agricultural commodities over the near future at their 1994 values. But this would mean that by the year 2001 agriculture will be protected more than the industry. During the period until 1980 Turkey has tried to assign more importance to industry relative to agriculture through complicated systems of tariffs, quotas and overvalued exchange rates. After 1980 Turkey tried to achieve the same result through the use of tariffs and tariff like charges. In order to avoid changing the incentive structure Turkey may have to reduce gradually the N PR's on agricultural commodities.

\section{Macroeconomic Issues}

With the formation of the $\mathrm{CU}$ the import tax revenue will be reduced substantially. Calculations using the 1990 input-output table of Turkey and the sectoral NPR's reported in Table 2 reveal that the annual tax revenue will be reduced by about $\$ 2.5$ billion. The government in order to compensate the loss in tax revenue amounting to $\$ 2.5$ billion has been trying to find solu- 
large corporations raising the VAT rate would just increase the tax burden of the corporations. The raising of additional taxes amounting to $\$ 2.5$ billion by VAT seems to face certain problems. Thus the government either has to reduce the government expenditures by $\$ 2.5$ billion or find ways of collecting the amount of $\$ 2.5$ billion by improving the efficiency of taxation in the country. But in either case output in the short run could decrease and unemployment increase. In the long run the employment problem will be solved through adjustments. Finally one should also note that the reduction of NPR's will lead to increases in imports over time leading to deterioration of balance of payments. Thus real depreciation of the currency seems inevitable.

Regarding the effects of the CU on FDI flows we note that Turkey is a middle income developing country with a fairly well developed infrastructure including communication, transportation, finance and banking. Geographically she is well placed to service a number of countries in the region. Yet, the volume of FDI is low compared with the amount harbored by several other developing countries at a similar stage of development. Turkey after establishing the $\mathrm{CU}$ with $\mathrm{EU}$ will implement the competition policies of $\mathrm{EU}$ and also insure adequate and effective protection and enforcement of intellectual, industrial and commercial property rights. These are measures that will increase the FDI into Turkey. Turkey will be able to attract more FDI than before as long as the country will be able to achieve political, social and macroeconomic stability (price and exchange rate stability with relatively high rates of sustainable growth). Given the immobility of labor between the parties, EU capital will seek the relatively cheap Turkish labor force. Capital is expected to flow into sectors where value added and hence profitability will increase with the formation of the CU. These sectors will consist among others of clothing, agriculture, food processing and service sec- 
enable the EU, American and J apanese companies to use Turkey as a joint investment and export base for the $\mathrm{M}$ iddle East and Eurasia. As a result Istanbul is emerging as the city of headquarters for operations in the Caucasus and Central Asia by the transnational companies.

Finally we should note that the Customs Union Agreement is silent on four issues: (i) supply of services, (ii) establishments, (iii) movement of capital, and (iv) movement of labor. According to Article 36 of the Additional Protocol the rights to freedom of movement and eligibility for social benefits in EU for Turkish immigrant workers and their families should have been achieved in progressive stages by no later than December 1, 1986. But because of major changes in the labor market situation in $E U$ since the early 1970's the objective could not be achieved. Currently there is a ban on the recruitment of migrant workers by $E U$ countries from Turkey and Turks face visa requirements visiting EC countries. The CUD is silent on supply of services, establishments and movement of labor mainly because EU wants the immigration gates to remain closed for the foreseeable future. Regarding capital mobility we note that as of 1995 there were no restrictions on capital movements in neither EU nor Turkey. Free movement of capital is thus taken as granted in the CUD.

\section{Conclusion}

From the point of view of Turkey, $\mathrm{CU}$ with the $\mathrm{EU}$ is desirable mainly as the $E U$ is and shall be the major trading partner of Turkey and the $E U$ is likely to be the major source of technology and investment for Turkey in the coming decades. As an economic integration model, membership to the EU is the first best option for Turkey. But the chances of Turkey becoming a member of the EU in the near future are rather dim. In the long run Turkey 
resource allocation and thus to increases in per capita income. The policy makers in Turkey are willing to bear the short run costs of establishing the $\mathrm{CU}$. It seems that the Turkish economy with the formation of the $\mathrm{CU}$ will have to bear all of the costs of adjustment without getting the kind of assistance that Greece, Portugal and Spain have received from EU when they joined the Community.

\section{References}

Anderson, K. and R. Tyers [1993], "Implications of E C Expansion for E uropean Agricultural Polices, Trade and Welfare," Centre for Economic Policy Research Discussion Paper Series, N 0. 829, London.

Commission of the European Communities [1996], "The CAP and Enlargement," E uropean E conomy, Reports and Studies, No 2.

Hoekman, B. M . [1995], "Trade Laws and Institutions: Good Practices and the World Trade Organization," World Bank Discussion Papers, Washington, D.C.

GATT [1993], Trade Policy Review M echanism: European Communities, Geneva.

Laird, S. and A.J. Yeats [1990], Quantitative Methods for Trade Barrier Analysis, The M acmillan Press Ltd., London.

Ozhan, G. [1994], "State Economic Enterprises in Turkey: An Analysis using Input-Output Techniques," Research Paper of "Turk Harb-Is" Labor Union, Ankara (in Turkish).

Togan, S. [1994], Foreign Trade Regime and Trade Liberalization in Turkey during the 1980's, Avebury, Aldershot. 